\title{
Retraction Note: Targeted suicide gene therapy for glioma using human embryonic stem cell-derived neural stem cells genetically modified by baculoviral vectors
}

\author{
Y. Zhao - D. H. Lam • J. Yang • J. Lin · C. K. Tham - W. H. Ng · S. Wang
}

Published online: 28 February 2020

(c) The Author(s) 2020. This article is published with open access

\section{Retraction Note to: Gene Therapy}

https://doi.org/10.1038/gt.2011.82.

The editor has retracted this article [1] following an investigation by Agency for Science, Technology and Research (A*STAR), Institute of Bioengineering and Nanotechnology, Singapore, which found evidence of fabricated animal survival data presented in Fig. $7 \mathrm{C}$ in the article to make the results statistically significant. DHL, JY, JL, CKT, WHN, and $\mathrm{SW}$ agree to this retraction. YZ has agreed to this retraction but not to the wording of this retraction notice.

Open Access This article is licensed under a Creative Commons Attribution 4.0 International License, which permits use, sharing, adaptation, distribution and reproduction in any medium or format, as long as you give appropriate credit to the original author(s) and the source, provide a link to the Creative Commons license, and indicate if changes were made. The images or other third party material in this article are included in the article's Creative Commons license, unless indicated otherwise in a credit line to the material. If material is not included in the article's Creative Commons license and your intended use is not permitted by statutory regulation or exceeds the permitted use, you will need to obtain permission directly from the copyright holder. To view a copy of this license, visit http://creativecommons. org/licenses/by/4.0/.

\section{References}

1. Zhao Y, Lam D, Yang J, et al. Targeted suicide gene therapy for glioma using human embryonic stem cell-derived neural stem cells genetically modified by baculoviral vectors. Gene Ther. 2012;19:189-200. https://doi.org/10.1038/gt.2011.82 